\title{
A Review Paper on Monitoring Environmental Consequences of Land Cover Dynamics with The Help of Geo-informatics Technologies
}

\author{
Ziyad Ahmad Abdo ${ }^{1, *}$ and Satya Prakash ${ }^{2}$ \\ ${ }^{1}$ Department of Public Relation and Communication, Ethiopian Ministry of Health, Addis \\ Ababa, Ethiopia \\ ${ }^{2}$ Department of Civil Engineering, Sharda University, Greater Noida, Uttar Pradesh, \\ 201310, India \\ *Corresponding Author : ziyadahm1982@gmail.com
}

Received 22 June 2020/ Revised 12 October 2020 / Accepted 21 October 2020/ Published 30 December 2020

\begin{abstract}
Land cover dynamics is a challenging and vigorous process that associates natural and human systems that have undeviating effects on atmosphere, water and soil which lead to many environmental problems worldwide. Urbanization is one of a major land cover change that is highly correlated with many environmental problems that need emphasis. This paper aimed to review and present level and effect of land use land cover changes, urbanization, factors affecting land cover change and application of geographic information system \& remote sensing in monitoring land cover changes. Over the past 300 years, about 1.2 million kilometer square of forests and 5.6 million kilometer square of pasture and rangeland were replaced by other uses worldwide, while cultivated land increased by 12 million $\mathrm{km}^{2}$. In 1950, only 30 percent of the world population lived in urban settings, the fraction raised to $55 \%$ by 2018 . This led to about roughly $60 \%$ of the ecosystem services are being destroyed or used in unsustainable ways worldwide. Population expansion, change of technology, high land value, corruption, lack of awareness, migration of people and political pressure are among major driving force of land cover changes. Geo-informatics technology specially GIS and Remote Sensing is found to be an excellent tool for study of land cover change that enables observation across large area of earth's surface with low cost, better efficient and high accuracy. Therefore monitoring, analyzing and evaluation of land cover dynamics with the help of geo-informatics is decisive for improved management \& characterizing land cover alteration processes, and determining its environmental consequences.
\end{abstract}

Keywords : land use; land cover change; urbanization; GIS \& remote sensing; environment

\section{Introduction}

Land cover shows the physical coverage of surface of land by water, vegetation, bare soil or non-natural structures (Verburg et al., 2009; Wossenu, 2016). Natural science experts explain land use based on forms of human activities such as planting, agriculture and buildings that modify surface processes, including geological activities, biodiversity and 
hydrology (Popović, 2017). Land administrators describe land use more widely to comprise social and economic activities and system in which land is managed, for example the existence of marketable agriculture, rented houses, and private land (Erle, 2007).

Land cover dynamics are the changes in physical and biological features of land that can be attributed to management, including the alteration of pastures and forest area into agricultural lands, urban settlements, contamination and degradation of the soil, vegetation removal and transition to non-agricultural uses (Jokar, 2011; Tesfa et al., 2016). Different experts explain land use land cover change (LULCC) as the modification of surface of the earth by human beings. These changes assimilate the extreme environmental suffering of today's human populations that include climate change, the loss of biodiversity and contamination of water, soil and atmosphere (Erle, 2007).

Changes in land cover can vary from a change in the character of the landscape without affecting existing global classifications to the extreme case in which one type of land cover completely replaces another (Gregorio, 2002; Molders, 2012). Land cover modification refers to human activities like deforestation for agricultural and urban expansion or that naturally caused by floods, forest fires, diseases epidemics and other natural disasters (Molders, 2012; Pielke et al., 2011). The place, time and spatial measures of several Land Cover Changes (LCCs) differ from each other due to their causes (Molders, 2012).

The extent of this alteration can be slow or immediate. For example, a forest fire causes sudden change, while the accumulation of biomass or the migration of ecosystems occurs gradually (Terefe, 2017). The change of LULC is a most important problem with respect to the changing comprehensive environment (Jing, 2007) as it is never static and is constantly evolving in reply to the forceful interaction of drivers and the responses of changes in land use (Mercy \& Matheaus, 2016; Terefe, 2017). Thus environmental systems are difficult to adapts as they arises from the connections among the various components of the system, which in turn influence the successive growth and its collaboration (Lepers, 2014).

The changes in land use are the global concern of the 21 st century, with an intense participation for human existence and they play a vital role in the study of main ecological change (Jing, 2007). Changes in LULC caused by both human and/or anthropogenic activities have fundamentally led to several environmental complications such as deforestation, biodiversity damage, increase in global temperature, increased flooding, etc. These ecological problems are often correlated with immense urbanization, agricultural and demographic pressure (Stéphenne \& Lambin, 2001) leading to a reduction of ecosystem services. 
Ecosystems provide many services to the living being (Grafius et al., 2016; Karen et al., 2017; Terefe, 2017). Some of these services include providing basic needs like food, water, fuel, and fibers. These ecological services support the nutrient cycle, soil formation, microclimate and macroclimate regulation, flood regulation, disease prevention, water purification, and other services supporting living things (Walter et al., 2005). Negative consequences of LULCC can result in a huge ecosystem service burden.

Analyzing LULCC detection is very important to understand global environmental transformation processes (Prashant \& Dawei 2012). Hence, consideration of the impacts of LULCC is becoming progressively more important. The need to acclimatize to climate change and continuous ecological inconsistency become important issues internationally, in addition to raising consciousness of the significance of environmental change regulation (Pielke et al., 2011). Therefore, analyzing, monitoring and evaluation of LULC, urbanization and their environmental consequence are very crucial for the land planner, manager, governmental and other NGO. Besides scientific community, to realize policies and strategies, improves the use of natural resources and minimizes the impact on the environment. Taking the above truth into consideration, it is critical to review and provide additional information to those in need. Therefore, in this paper, the authors have reviewed LULCC and its environmental impact, and the application of Geo-informatics technologies such as, GIS and remote sensing for LULCC studies.

\section{Land Use Land Cover Change (LULCC)}

The LULCC is an endless process that has taken place on the surface of the earth since ancient time (Gebrekidan, 2014; Shiferaw, 2011). For many years, human societies have been living together modifying and changing the natural environment (Andreas et al., 2013).Over the past 300 years, about 1.2 million kilometer square of forests and 5.6 million kilometer square of pasture and rangeland were replaced by other uses worldwide, while cultivated land increased by 12 million $\mathrm{km}^{2}$ (Chetan et al., 2002). After 1990, humans converted the environment faster and more widely than throughout any equivalent time period in human history, principally to fulfill the increasing demand for food stuff, water, wood, fibers and fuels. This has caused in a considerable and mostly irreparable damage of the variety of life on Earth (Pielke et al., 2011; Walter et al., 2005). For example, since 1950 about $30 \%$ of forest area changed to crop land. Roughly $60 \%$ of the ecosystem services are being destroyed or used in un sustainable ways worldwide (Walter et al., 2005). 
A study (Pielke et al., 2011) shows that, globally total cultivated area has increased considerably, from 12 million hectares in 1871 to almost 70 million hectares at the end of the twentieth century. Most of studies reviewed in this paper and related with LULCC show that, evergreen forests, grasslands and bare lands decreased extensively, while agricultural land and built-up has increased (Abebe \& Megento, 2016; Halefom \& Teshome, 2018; Mercy \&, Matheaus, 2016). For instance, it indicates that evergreen forests decline from $39 \%$ in 2000 to 17\% in 2016 (Mercy \& Matheaus, 2016). Similarly, another study demonstrated that the reduction of green spaces plantations, forest, grass and cultivated land at yearly rates of 5.9\%, $3.3 \%, 5.4 \%$ and $3.7 \%$ respectively during 1986 to 2015, while built-uncover increased at annual rate of $5.7 \%$ (Abebe \& Megento, 2016).

LULCC has impact on water basins. Hydrological practices of watersheds are affected by different causes such as, LULCC, climate, earth physicochemical properties, geology of the place, landscape, and spatial \& temporal connections between these factors (Charles, 2016; Roland, 2000). Soil degradation, loss of biodiversity, and environmental damage (Mikias, 2015; Tadesse, 2014; Tesfa et al., 2016) are some of the major consequences of LULCC worldwide.

On the positive side, some changes in LULC have paid a substantial profit in terms of human welfare and economic growth. However, these advances were experienced at a high loss in the form of distraction of uncountable ecosystem services, amplified jeopardies of nonlinear changes and the escalation of poverty for some groups of people (Summers \& Linthurst, 2012).To determine the values of ecosystem services analyzing the LULC and a global database is important. For example, a study by Terefe (2017) showed that, due to forest cover reduction by $54.2 \%$ in four decades led to nearly US \$ 3.69 million intimated ecosystem services were lost.

LULCC is intricate and interconnected such that the enlargement of one kind take place at the expense of other classes (Molders, 2012; Pielke et al., 2011). Detection, analysis and modeling of changes in LULC and driving forces are important to establish the cause and effects detected in the past, as well as to predict future changes in LULC (Hassan et al., 2016; Tesfa et al., 2016), are also tremendously important systems for land managers and decision makers (Crews-Meyer, 2002).

\subsection{Urban Land Cover Dynamics and Urbanization}

Urbanization is one of the further most dominant \& observable social activities on Earth (Dawson, 2009). Urban development and LCC are the two most correlated issues 
studied in different scientific papers. It is one of anthropogenic results that shows a global trend and reflects the growth of the world's population. Hence, the growth of population can result in expansion and modification of urban land. This led humans to undergoing a radical change in urban life (Grimm et al., 2008; Montgomery, 2008). It is obvious that cities intrude towards peripheries at the expense of farm lands, forest and other natural resources (Tawhida et al., 2015). The aesthetic benefits from open spaces, the livelihood of farming communities at the pre urban area are being increasingly changed by urban settlements (Mengistu, 2016; Yared \& Heyaw, 2019). Understanding urban LCC is crucial for improved understanding of their fundamental characteristics and processes, and the impact of LCC on environment (Bagan \& Yamagata, 2014).

At the beginning of $20^{\text {th }}$ century, almost merely $10 \%$ of the world's population was living in urban areas (Grimm et al., 2008). Today, the world has been urbanizing more rapidly. In 1950, only 30 percent of the world's population lived in urban setting, this number increase to 55 percent in 2018 (United Nation, 2018b). The population changes and the expansion of megacities are leading to the transformation of forests and agricultural areas into urban agglomerations (Kumar et al., 2018; Liu et al., 2014). The estimates of the global urban area varies from 1 to $3 \%$ of the land surface (Liu et al., 2014; United Nation, 2018a). This difference of coverage is because different studies define urban land in different way (example; "cities area", "Urban administrative area", area conquered by built-up areas", "built up area", "impervious surface” etc.) (Liu et al., 2014). Worldwide, the number of large metropolitan is anticipated to increase from 33 in 2018 to 43 in 2030 (Nation, 2018).

\subsection{Consequences of Urbanization and Other Land Cover Change}

Even though the urbanization process has important implications for economic development (Chen et al., 2014; Henderson, 2003; Mcgranahan, 2013), unplanned, nonsystematic and rapid urban growth have intense impacts on several ecological constituents, particularly land, water and air (Bisrat et al., 2018; Cui \& Shi, 2012; Patra et al., 2018; Seto, et al., 2012). This is especially true since many of the urban areas of the world have experienced significant LCC for many years. Hence, those urban areas use the greatest amount of world's energy (Cui \& Shi, 2012; Liu, 2009) and result in severe ecological complications (Cui \& Shi, 2012; Popović, 2017) like deprivation of air and water quality, and exacerbation of land degradation (Battista \& de Lieto Vollaro, 2017; Patra et al., 2018; Yan, et al., 2016). Urbanization has also resulted in an enormously serious public health issues (Gebrekidan, 2014; Popović, 2017; Walter et al., 2005). 
The interchange of energy, water, and exchanges between land cover and the atmosphere is highly affected by the physical features of land cover (Cui \& Shi, 2012). In the growth of urban land, forests, vegetation cover, other natural and man-made plants are mostly changed to paved surfaces. This can significantly affect natural processes and ecosystem services. For example the urbanization process affects precipitation patterns, this in turn affect ground water levels (Patra et al., 2018).

Increased urban land cover has substantial effects on local environment and weather, and also interferes with many natural processes (Cui \& Shi, 2012), like inconsistency of rainfall, relative humidity and surface water quality (Cui \& Shi, 2012; Tolera, 2018). The urban heat island (UHI) is increased by the expansion of the urban landscape, in contrast to rural areas (Wossenu, 2016). Wind speed and direction are also affected by urban land expansion (Mohan \& Kandya, 2015; Yan et al., 2016; Bisrat et al., 2018; Srivastava \& Satyaprakash, 2020). This all can affect air quality and result in public health problems (Tawhida et al., 2015). For instance, studies in some portions of the northern hemisphere show that, on average urban areas get $12 \%$ less solar radiation, $14 \%$ additional precipitation, $8 \%$ more clouds, $10 \%$ more snowfall, and $15 \%$ more storms, in addition the concentration of pollutants is 10 times greater and the areas are $2^{\circ} \mathrm{C}$ more warmer when compared to their rural counterparts (Taha, 2008).

LULCC also takes a main role in climate change from global to local scales (Erle, 2007; Zhang et al., 2015). As land cover changes, degradation of the forest and different plants reduce the potential for carbon storage and sequestration (Reda, 2017). Dynamics of land cover change the terrestrial carbon balance (Zhang et al., 2015). In history large amount of carbon dioxide were released into the environment because of LULCC. This had extraordinary impact on local to global atmospheric amount of carbon dioxide and the earth energy balance (Pielke et al., 2011). Therefore, a detailed understanding and monitoring of the change of LULC and urban growth, and their possible consequences is necessary to manage environmental problems and facilitate sustainable development.

\subsection{Factors Affecting Land Use and Land Cover Change}

Knowledge of drivers of LULCC is used to mark the beginning of the cause-effect relationship seen in the previous story. It is also very useful for land managers and policy makers to help forecast the future LULCC and its effect (Erle, 2007). While much effort has been devoted to identifies the factors, many test results show that LULCC drivers continue to change from time to time depending on specific problems. The drivers of change in the 
ecosystem have global, regional and local contacts (Molders, 2012; Walter et al., 2005). The instantaneous evolution and enlargement of urban centers, the pressurized population growth, immigration to cities, the shortage of land, the need for increased production, and technological changes are among the many driving forces for LULCC in today's world (Song, 2011; Cui \& Shi, 2012; Kindu et. al., 2015; Mikias, 2015; Tolera, 2018). Additionally a study in Shanghai, China show that beside population growth, policy reform and economic development are among the drivers of LULCC (Cui \& Shi, 2012). A study done in Khartoum, Sudan shows that natural conditions, the countries government policy, interaction among people and industrial growth were the main drivers of the LULCC experienced (Galal, 2015). Furthermore a study of Sabata, Ethiopia showed that factors for urban green space reduction are the extension of the built up land and transport area, population growth, high land value, weakness of planning\& regulations, corruption, absence of coordination between concerned organizations, and limited awareness of the importance of green spaces (Yared \& Heyaw, 2019). Large scale lands that lack suitable environmental impact assessments and unplanned community relocation systemwere among the specified cause of massive LULCC (Azeb et al., 2018).

Land covers change and different driving forces are related in different ways. Rapid expansion in urban areas due to population and economic growth increases the ultimatum for natural resources and causes change in land use, especial ly in urban centers (Halefom \& Teshome, 2018). The interactions between the different socio-economic conditions, population pressure, physiographic characteristics and the type of land use have led to a change in the land use (Azeb et al., 2018; Tesfa et al., 2016; Walter et al., 2005). As migration to cities is one of the LULCC drivers it is caused by lack of employment, insecurity, reduction of agricultural productivity, lack of human life facilities, poverty, drought and natural disasters (Tawhida et al., 2015). Therefore understanding thedrivers of changes in LULC is critical for modeling future land dynamics and development of management strategies to prevent further decline of natural resources and prevention environmental problems (Song, 2011).

\section{The Role of Remote Sensing and GIS in Land Use/Land Cover Analysis}

Strong, accurate, consistent and updated information systems on LULCC and urbanization trends are needed for possibilities of choice, planning, forecasting and execution of land use arrangements to encounter the growing burdens for rudimentary human requirements, welfare and sustainable LULC development (Stéphenne \& Lambin, 2001; 
Zhang et al., 2018).With the passage of time, different technologies gets developed making asimpler and more efficient. Geo-informatics technologies, which mainly include Satellite Remote Sensing (RS) and Geographic information system (GIS), are widely implemented for assessing and characterizing LULCC (Hassan et al., 2016).

Remote sensing has recognized to be a wonderful tool for monitoring the Earth's surface to improve perception of our environment, leading to unprecedented advancements in sensor and information technology (Al-wassai \& Kalyankar, 2013; Weng, 2016).The Earth observation satellites offer a wide variety of image data with different characteristics in terms of spatial, spectral, radiometric, temporal resolutions and data volume (Al-wassai \& Kalyankar, 2013). The introduction of the Earth Resource Technology Satellite (ERTS) 1, later called Landsat 1 in July 1972, has contributed significantly to the development of remote sensing applications such as land cover classification (Phiri \& Morgenroth, 2017).

Specially space based systems are very important instruments of land change study because they enables visualizing wider area of Earth's surface compared to ground based methods (Mubea \& Menz, 2012). In RS the ground surface is identified based on color provided for each land cover type which is emanate from the different reflected energy from ground surface features. RS provides outstanding databases from which well-organized information on LULCC can be generated, analyzed and modeled (Alqurashi \& Kumar, 2013; Barani \& Seelam, 2018; Mubea \& Menz, 2012) in minimum time with very low cost and better accuracy (Halefom \& Teshome, 2018; Kumar et al., 2015). This method empowers researchers/academicians/students to examine and model LCC efficiently and effectively. Similarly, GIS is used to store and handle large data sets about the images and all related information to enable analysis, interpretation and finally application according to choice of interest (Sadoun \& Al Rawashdeh, 2009).

Historical qualitative and manual measuring systems are currently unable to satisfy the expanded need for scientific studies of land change management, the development of satellite RS starting from the early 1970s delivering data for the active follow up and measurable analysis of LULCC (Yue et al., 2018).

As RS has a high value for self-determining and as an objective source of information for LULCC (Ali Khawaldah, 2016; Halefom \& Teshome, 2018), many researchers have shown evidence of the effectiveness of RS technology for LULC study (Awoke, 2010; Barani \& Seelam, 2018). Specially integrating RS and GIS can provide a tremendous method for ideal LULC planning and management (Rozenstein \& Karnieli, 2011; Sadoun \& Al 
Rawashdeh, 2009; Weng, 2016). Most of the important processes in LULC assessment using RS and GIS may be listed as follow.

\subsection{Selection of Remotely Sensed Data}

RS data are a practical source of data that land use maps can be created from and managed efficiently (Rozenstein \& Karnieli, 2011). The selection of suitable sensor data is the most significant step for an effective image classification. RS data vary in spatial, spectral, radiometric, and temporal resolutions (Phinn, 1998). Additionally, criteria such as image acquisition time, cloud cover, atmospheric condition, data formats, data charges and other are considered to select suitable image (Thomas \& Ralph, 2015; Weng \& Lu, 2007). Currently, in addition to the above platforms, LANDSAT Operational Land Imager (OLI 8) and Sentinel 2 MSI (multispectral instrument) are widely used. In general LANDSAT satellites are a main data source for global to regional LULC analysis (Prashant \& Dawei, 2012), because of the easy and free availability of the data. Apart from the above, there are many other satellite platforms such as IKONOS, GeoEye, LIDAR, etc., which are also used for LULCC studies. However, before using the satellite image, prioritization of different types of sensor and other GIS data is critical for the selection of appropriate data for intended purpose (Padmanaban et al., 2017; Phinn, 1998).

\subsection{Image Pre Processing}

The raw satellite image may not be directly used for intended applications and needs some modifications and correction. There are some pre-processes that must be done on the raw image before it can be used for further refinement, interpretation, or analysis. Some of these processes are designed to correct errors that could lead to data being secretly collected, while others make the data more sensitive for further processing (Thomas \& Ralph, 2015). Pre-treatment activities include noise and haze removal, radiation correction, geometry correction, sub image preparation, mosaic, and stacking are among pre-processing activities (Obodai et al., 2019; Padmanaban et al., 2017; Weng \& Lu, 2007). A first step in preprocessing is for individual bands of each scene need to be stacked to create a multispectral image for each scene. The second step of image preprocessing is image extraction/sub setting of an Area of Interest (AoI). Subtracting the AoI from the entire part of the image is important to reduce the bulkiness of the image file. This is not only removes unnecessary data in the image, but also it increase processing speed because of the reduced extent of data to work on (Prashant \& Dawei, 2012). 
Subsequently geometric, radiometric corrections and image enhancement are conducted. Geometric correction involves removing orientation distortion and it also involves changing of data to ground coordinates (Herold et al., 2002; Otukei \& Blaschke, 2010). The sources of these distortions may be the speed of the sensor platform, difference in altitude, earth curvature, atmospheric deflection and refraction (Thomas \& Ralph, 2015). On the other hand, radiometric correction includes correction for atmospheric noise or unwanted sensor and data correction for sensor irregularities is needed (Abebe \& Megento, 2016; Padmanaban et al., 2017). Image enhancement is to enhance the appearance of images to aid visual analysis, classification and interpretation of images (Abebe \& Megento, 2016). However, for digital image processing of the satellite images, image enhancement might not be needed.

\subsection{Classification System}

Image classification involves categorizing the corrected stacked images or the individual panchromatic images into a fewer number of individual land use land cover classes or themes, based on the reflectance values (Thomas \& Ralph, 2015). This can increase and simplify the applicability of RS data. There are two types of image classifiers system, which are supervised and unsupervised. It is important to know that there is no single perfect one in which image can be classified (Thomas \& Ralph, 2015). The major difference among this two method of classification is, in supervised classification first training site development comes which is followed by classification stage (Rozenstein \& Karnieli, 2011; Thomas \& Ralph, 2015). In other way in the unsupervised system, first image is classified based on natural spectral grouping, then the image expert defines land cover identity and group them according to their similarity by comparing with ground truth data (Thomas \& Ralph, 2015).

There are many classification algorithms in supervised classification. Maximum likelihood classifier, parallel epiped classifier, minimum likelihood classifier, spectral angle mapper, object-based classification, neural network machine hearing, deep learning classification and a spectral correction mapper are the major ones that are often used (Thomas \& Ralph, 2015). The maximum likelihood classification method applies the theory of probability to classification activities and is generally work based on statistics (mean, variance/covariance). It is the most powerful/common classifier and mostly employed (Ayele, et al., 2018; Kebede, 2018). This method has been used by many researchers, for example many articles reviewed by the authors (Alqurashi \& Kumar, 2013; Hernández-Guzmán et al., 2019) used this method. Identifying appropriate classification system and algorithm is among the main activities need for LCC change study. 


\subsection{Accuracy Assessment}

It is necessary to validate to what degree the produced classification is similar with what exists on the ground. It is significant for accepting the obtained results and making good decisions (Gashu \& Egziabher, 2018; Obodai et al., 2019). Accuracy assessment is also needed to reduce the error in RS data (Alqurashi \& Kumar, 2013). Source of reference data, sampling system, and sample size must be taken into account to properly develop an error matrix for accuracy assessment (Mausel et al., 2004; Padmanaban et al., 2017).

Collection of the reference data is a key element of an accuracy assessment. Reference data is the data that is to be compared against classified image. Different researchers use different system to collect reference data, also called ground truth. For instance, ground observation using GPS (Faye et al., 2016; Hailemariam et al., 2016; Park, 2016), aerial photography (Hailemariam et al., 2016), available thematic maps interpretation (Ghosh \& Das, 2019; Sarkar, 2018) and Google earth images (Alqurashi \&Kumar, 2013; Bisrat \& Gizaw, 2018; Herold et al., 2002) can be used. The most common sampling system that is used for collecting reference data is simple random sampling, systematic sampling, stratified random sampling, cluster sampling, and stratified systematic (Padmanaban et al., 2017). Different researchers use different sample sizes calculation for reference data. On the other hand, classifications covering large areas or with more than 12 land cover categories require more thorough sampling, typically 75 to 100 samples per category.

\subsection{Land Cover Change Detection}

Detecting changes in LCC is one of the most fundamental and common uses of remote sensing image analysis. It is the system of recognizing variation in the status of things or event by seeing it at different period of time (Mausel et al, 2004; Alqurashi \& Kumar, 2013). There are many LCC detection systems. Post-classification comparison, Change vector analysis (CVA), Image differencing, image rationing, , chi-square, decision trees, image fusion, hybrid change detection, principal component analysis (PCA), artificial neural networks (ANN) are among the major methods (Alqurashi \& Kumar, 2013; Mausel et al., 2004; Thomas \& Ralph, 2015).

All techniques have their own pros and cons. For example, post-classification comparison gives more detail about the image, object that are selected and change detected. On other hand, image differencing, image rationing, and principal components analysis, do not provide sufficient change trend information (Alqurashi \& Kumar, 2013), therefore it is 
difficult to determine trend and direction of changes. Several other change detection techniques, such as image differencing, image rationing, PCA, chi-square, hybrid change detection and CVA, require the selection of a threshold. Even though selecting an appropriate threshold is essential for gaining good change detection results, selecting an appropriate threshold is challenging and time consuming. Furthermore, the strengths and limitations of individual change detection techniques should be considered while selecting any technique for a specific study.

Even though selecting training site (STS) is important for good output of change detection as required by analysts, it is time consuming. However, some change detection techniques such as post-classification comparison, artificial--neural networks, need STS. Change direction is specified by whether the change is positive or negative in each band on a pixel by pixel basis. The direction of change show whether detected character is increasing or decreasing. However, some change detection techniques such as, Hybrid-change detection, Image-fusion, Image-differencing, Chi-square and some others does not provide change direction (PCD). A challenge in change spectrum determination method is to distinguish the pixel change from chain of incoherent data. For most change detection methods, the choice of the threshold value decides the competency of change detection. Selecting aappropriate threshold value can maximize separating the areas of real changes. Some change techniques such as Hybrid-change detection, Artificial-neural networks, GIS-technique do not require selecting suitable threshold. At the end of the change detection process, structured change matrix is very important for interpretation. Hence, some change detection techniques such as Post-classification comparison, Artificial-neural networks, GIS-technique doprovide change matrix (PCM).

A comparison of many of the LULCC detection techniques have been compiled in the Table 1. The table lists down the characteristics of the technique, its strengths and limitations and additional features (STS: SelectingTraining Site, PCD: Providing Change Direction, ST: Selecting Threshold, PCM:Providing Change- Matrix) required to operate. Yes or No in the table shows that whether the technique is needed or not required tocarry out the LCC process. For example, those techniques which need selecting training site is coded as Yes under STS column and for those techniques which do not need selecting training site is coded as No in the STS column. Similarly, those which provide change direction is coded as Yes in the PCD column and those which do not provide change direction is coded as No under PCD column. The information has been compiled from different literature. The references are mentioned in the last column separately. 
Ziyad Ahmad Abdo and Satya Prakash / GEOSI Vol 5 No 3 (2020) 364-389

Table 1. Features of some change detection techniques (Explanation is in the text)

\begin{tabular}{|c|c|c|c|c|c|c|c|c|}
\hline \multirow{2}{*}{$\begin{array}{l}\text { Change detection } \\
\text { techniques }\end{array}$} & \multirow[t]{2}{*}{ Change detection system } & \multirow[t]{2}{*}{ Strength } & \multirow[t]{2}{*}{ Limitations } & \multicolumn{4}{|c|}{$\begin{array}{l}\text { Additional features required } \\
\text { to operate }\end{array}$} & \multirow[t]{2}{*}{ References } \\
\hline & & & & STS & PCD & ST & PCM & \\
\hline $\begin{array}{l}\text { Post classification } \\
\text { comparison }\end{array}$ & $\begin{array}{l}\text { Categorizes multi-temporal } \\
\text { images into thematic maps } \\
\text { separately, then performs a } \\
\text { pixel-by-pixel comparison } \\
\text { of categorized image }\end{array}$ & $\begin{array}{l}\text { Reduces the effects of } \\
\text { atmospheric, sensor and } \\
\text { environmental variances } \\
\text { between satellite images; } \\
\text { Provides a complete } \\
\text { information about change } \\
\text { matrix }\end{array}$ & $\begin{array}{l}\text { It takes a lot of time and } \\
\text { experience to build } \\
\text { Sorting products. The final } \\
\text { accuracy depends on the quality of } \\
\text { the image classified for each date }\end{array}$ & Yes & Yes & No & Yes & $\begin{array}{c}\text { (Afify, 2011; } \\
\text { Almutairi \& } \\
\text { Warner, 2010; } \\
\text { Alqurashi \& } \\
\text { Kumar, 2013; Bay } \\
\text { \& El-hattab, 2016) }\end{array}$ \\
\hline $\begin{array}{l}\text { Hybrid change } \\
\text { detection }\end{array}$ & $\begin{array}{l}\text { Trap optimization is used } \\
\text { to isolate variable pixels } \\
\text { from a particular image, } \\
\text { followed by supervised } \\
\text { classification. The binary } \\
\text { swap mask is generated } \\
\text { from the results of the } \\
\text { classification. This change } \\
\text { mask filters the changed } \\
\text { properties of the LULC } \\
\text { maps generated for each } \\
\text { date. }\end{array}$ & $\begin{array}{l}\text { This method subtracts the } \\
\text { unaltered pixels from the } \\
\text { gradation to reduce } \\
\text { Classification errors }\end{array}$ & $\begin{array}{l}\text { Identifying pathways for change is } \\
\text { quite complicated }\end{array}$ & No & No & Yes & No & $\begin{array}{c}\text { (Alqurashi \& } \\
\text { Kumar, 2013; } \\
\text { Mohamed \& } \\
\text { Mobarak, 2016) }\end{array}$ \\
\hline $\begin{array}{l}\text { Artificial neural } \\
\text { networks }\end{array}$ & $\begin{array}{l}\text { The input used to train a } \\
\text { neural network is spectral } \\
\text { data from the period of } \\
\text { change. The reverse } \\
\text { propagation algorithm is } \\
\text { often used to train a } \\
\text { multilayer neural network } \\
\text { model. }\end{array}$ & $\begin{array}{l}\text { Has the ability to predict } \\
\text { data properties based on } \\
\text { training examples }\end{array}$ & $\begin{array}{l}\text { It is difficult to know nature of the } \\
\text { hidden layers; Long training time } \\
\text { is required, ANN is generally } \\
\text { sensitive to the amount of training } \\
\text { data used and ANN functions are } \\
\text { uncommon in image processing } \\
\text { software }\end{array}$ & Yes & Yes & No & Yes & $\begin{array}{l}\text { (Alqurashi \& } \\
\text { Kumar, 2013; } \\
\text { Mohamed \& } \\
\text { Mobarak, 2016; } \\
\text { Prashant et al., } \\
\text { 2012) }\end{array}$ \\
\hline Image fusion & $\begin{array}{l}\text { Estimate the ratio of } \\
\text { registered image of } \\
\text { different dates band-by- } \\
\text { band. }\end{array}$ & $\begin{array}{l}\text { Minimize effects of Solar } \\
\text { angle, of shadow and } \\
\text { terrain }\end{array}$ & $\begin{array}{l}\text { Anomalous distribution of the } \\
\text { result is often critiqued }\end{array}$ & No & No & Yes & No & $\begin{array}{l}\text { (Alqurashi \& } \\
\text { Kumar, 2013) }\end{array}$ \\
\hline
\end{tabular}

Continued.... 
Ziyad Ahmad Abdo and Satya Prakash / GEOSI Vol 5 No 3 (2020) 364-389

\begin{tabular}{|c|c|c|c|c|c|c|c|c|}
\hline \multirow{2}{*}{$\begin{array}{l}\text { Change detection } \\
\text { techniques }\end{array}$} & \multirow[t]{2}{*}{ Change detection system } & \multirow[t]{2}{*}{ Strength } & \multirow[t]{2}{*}{ Limitations } & \multicolumn{4}{|c|}{$\begin{array}{l}\text { Additional features required } \\
\text { to operate }\end{array}$} & \multirow[t]{2}{*}{ References } \\
\hline & & & & STS & PCD & ST & PCM & \\
\hline GIS technique & $\begin{array}{l}\text { Combine past and current } \\
\text { land use maps with } \\
\text { topographic and geological } \\
\text { data. Image wrapping and } \\
\text { binary masking techniques } \\
\text { are useful for measuring } \\
\text { the dynamics of change in } \\
\text { each class. }\end{array}$ & $\begin{array}{l}\text { This method allows } \\
\text { Antenna fusion } \\
\text { Photo data of current and } \\
\text { historical land use data } \\
\text { along with other map dates }\end{array}$ & $\begin{array}{l}\text { Different GIS data with different } \\
\text { engineering precision and } \\
\text { classification system reduce the } \\
\text { quality of the result }\end{array}$ & No & Yes & No & Yes & $\begin{array}{c}\text { (Alqurashi \& } \\
\text { Kumar, 2013; } \\
\text { Mohamed \& } \\
\text { Mobarak, 2016) }\end{array}$ \\
\hline $\begin{array}{l}\text { Image } \\
\text { differencing }\end{array}$ & $\begin{array}{l}\text { Subtracts the image of the } \\
\text { first date pixel by pixel } \\
\text { from the image of the } \\
\text { second date }\end{array}$ & $\begin{array}{l}\text { Result interpretation is } \\
\text { quite simple and easy }\end{array}$ & $\begin{array}{l}\text { Cannot provide a detailed change } \\
\text { matrix }\end{array}$ & No & No & Yes & No & $\begin{array}{l}\text { (Al-doski et al., } \\
\text { 2013; Almutairi \& } \\
\text { Warner, 2010; } \\
\text { Mishra \& } \\
\text { Dhurvey, 2018) }\end{array}$ \\
\hline Image rationing & $\begin{array}{l}\text { Estimate the ratio of } \\
\text { recorded images for two } \\
\text { date band-by-band }\end{array}$ & $\begin{array}{l}\text { Minimize effect of Solar } \\
\text { angle \&reduces the effects } \\
\text { of shading and terrain, is a } \\
\text { simple method to detect } \\
\text { changes in urban areas, and } \\
\text { better handles calibration } \\
\text { errors }\end{array}$ & $\begin{array}{l}\text { Anomalous distribution of the } \\
\text { result is often critiqued }\end{array}$ & No & No & Yes & No & $\begin{array}{c}\text { (Afify, 2011; } \\
\text { Alqurashi \& } \\
\text { Kumar, 2013; } \\
\text { Mishra \& } \\
\text { Dhurvey, 2018) }\end{array}$ \\
\hline $\begin{array}{l}\text { Change vector } \\
\text { analysis }\end{array}$ & $\begin{array}{l}\text { It produces two outputs: a } \\
\text { spectral change vector } \\
\text { defines the direction and } \\
\text { magnitude of the change } \\
\text { from the first to the second } \\
\text { date, and the total amount } \\
\text { of change for each pixel is } \\
\text { calculated by determining } \\
\text { the Euclidean distance } \\
\text { between the extremes } \\
\text { through the dimensional } \\
\text { change field }\end{array}$ & $\begin{array}{l}\text { Process any number of } \\
\text { spectral bands required and } \\
\text { generates detailed change } \\
\text { detection information }\end{array}$ & $\begin{array}{l}\text { Forms of land cover change were } \\
\text { difficult to identify }\end{array}$ & No & Yes & Yes & No & $\begin{array}{l}\text { (Almutairi \& } \\
\text { Warner, 2010; } \\
\text { Alqurashi \& } \\
\text { Kumar, 2013) }\end{array}$ \\
\hline
\end{tabular}

Continued.... 
Ziyad Ahmad Abdo and Satya Prakash / GEOSI Vol 5 No 3 (2020) 364-389

\begin{tabular}{|c|c|c|c|c|c|c|c|c|}
\hline \multirow{2}{*}{$\begin{array}{c}\text { Change detection } \\
\text { techniques }\end{array}$} & \multirow[t]{2}{*}{ Change detection system } & \multirow[t]{2}{*}{ Strength } & \multirow[t]{2}{*}{ Limitations } & \multicolumn{4}{|c|}{$\begin{array}{l}\text { Additional features required } \\
\text { to operate }\end{array}$} & \multirow[t]{2}{*}{ References } \\
\hline & & & & STS & $\mathrm{PCD}$ & ST & PCM & \\
\hline Chi-square & $\begin{array}{l}\mathrm{Y} \sim(\mathrm{X} 2 \mathrm{M}) \mathrm{T} \mathrm{S} 216(\mathrm{X} 2 \mathrm{M}) \\
\text { Y: numerical value of the } \\
\text { image change, } \\
\mathrm{X} \text { : vector of the difference } \\
\text { between six numerical } \\
\text { values between two dates, } \\
\mathrm{M} \text { : vector of } \\
\text { mean residuals for each } \\
\text { band }, \mathrm{T} \text { : cross section of } \\
\text { the matrix, S21: matrix of } \\
\text { six connected inverse } \\
\text { covariance }\end{array}$ & $\begin{array}{l}\text { Multiple bands } \\
\text { simultaneously used to } \\
\text { create a single change } \\
\text { image }\end{array}$ & $\begin{array}{l}\text { The assumption that } \mathrm{Y} \sim 0 \\
\text { represents an unchanged pixel } \\
\text { when most of the image is } \\
\text { changed is incorrect. Furthermore, } \\
\text { the change related to the specific } \\
\text { spectral orientation could not be } \\
\text { easily determined }\end{array}$ & No & No & Yes & No & $\begin{array}{c}\text { (Alqurashi \& } \\
\text { Kumar, 2013; Lu } \\
\text { \& Moran, 2004) }\end{array}$ \\
\hline $\begin{array}{l}\text { Principle } \\
\text { component } \\
\text { analysis }\end{array}$ & $\begin{array}{l}\text { Assume that data from } \\
\text { multiple time periods is } \\
\text { highly correlated and that } \\
\text { change information can } \\
\text { be distinguished into new } \\
\text { components. The two } \\
\text { methods of applying } \\
\text { a PCA } \\
\text { for change detection are: } \\
\text { (1) Put two or more image } \\
\text { dates in a file, then } \\
\text { perform a PCA and } \\
\text { analyze the images of } \\
\text { secondary components of } \\
\text { the change information; } \\
\text { And (2) do the PCA } \\
\text { separately, then extract the } \\
\text { PC image with the second } \\
\text { date from the PC image } \\
\text { corresponding to the first } \\
\text { date }\end{array}$ & $\begin{array}{l}\text { It minimizes data } \\
\text { redundancy between bands, } \\
\text { validates diverse } \\
\text { information in derived } \\
\text { components, and facilitates } \\
\text { easy classification of } \\
\text { changed and unchanged } \\
\text { area. }\end{array}$ & $\begin{array}{l}\text { PCA depends on the scene, so it is } \\
\text { difficult to perceive the variation } \\
\text { between different dates and to } \\
\text { interpret the results of the } \\
\text { denomination. It cannot provide a } \\
\text { complete change category } \\
\text { information matrix and requires } \\
\text { thresholds to define the variable } \\
\text { region }\end{array}$ & No & No & Yes & No & $\begin{array}{c}\text { (Afify, 2011; Al- } \\
\text { doski et al., 2013 } \\
\text { Almutairi \& } \\
\text { Warner, 2010; } \\
\text { Alqurashi \& } \\
\text { Kumar, 2013; } \\
\text { Devi, 2015) }\end{array}$ \\
\hline
\end{tabular}

Continued.... 
Ziyad Ahmad Abdo and Satya Prakash / GEOSI Vol 5 No 3 (2020) 364-389

\begin{tabular}{|c|c|c|c|c|c|c|c|c|}
\hline \multirow{2}{*}{$\begin{array}{l}\text { Change detection } \\
\text { techniques }\end{array}$} & \multirow{2}{*}{ Change detection system } & \multirow{2}{*}{ Strength } & \multirow{2}{*}{ Limitations } & \multicolumn{4}{|c|}{$\begin{array}{l}\text { Additional features required } \\
\text { to operate }\end{array}$} & \multirow{2}{*}{ References } \\
\hline & & & & STS & PCD & ST & PCM & \\
\hline Image regression & $\begin{array}{l}\text { Create relationships } \\
\text { between bi-temporal } \\
\text { images, then use the } \\
\text { regression function to } \\
\text { estimate the pixel values } \\
\text { for the second date image } \\
\text { and subtract the retracted } \\
\text { image from the first date } \\
\text { image }\end{array}$ & $\begin{array}{l}\text { Minimize the effects of } \\
\text { climatic, sensor and } \\
\text { environmental differences } \\
\text { between the two dated } \\
\text { image }\end{array}$ & $\begin{array}{l}\text { Requires development of correct } \\
\text { regression functions for specified } \\
\text { bandprior to implementing change } \\
\text { detection }\end{array}$ & No & Yes & Yes & No & $\begin{array}{l}\text { (Devi, 2015; Lu \& } \\
\text { Moran, 2004; } \\
\text { Mohamed \& } \\
\text { Mobarak, 2016) }\end{array}$ \\
\hline $\begin{array}{l}\text { Visual } \\
\text { interpretation }\end{array}$ & $\begin{array}{l}\text { A band of the image of } \\
\text { date } 1 \text { is red; the same band } \\
\text { of the image of date } 2 \text { is } \\
\text { green and blue if there is } \\
\text { the same band of the image } \\
\text { of date } 3 \text {. Visually interpret } \\
\text { the color complex to } \\
\text { identify changing areas. An } \\
\text { alternative is to digitize } \\
\text { variable regions on screen } \\
\text { using a visual } \\
\text { interpretation based on } \\
\text { overlapping images on } \\
\text { different dates }\end{array}$ & $\begin{array}{l}\text { Human expertise and } \\
\text { knowledge are helpful } \\
\text { during visual } \\
\text { interpretation. Two or } \\
\text { three image dates can be } \\
\text { analyzed simultaneously. } \\
\text { The analyst can add } \\
\text { texture, shape, size and } \\
\text { patterns to the visual } \\
\text { interpretation to make a } \\
\text { decision on the LULC } \\
\text { change }\end{array}$ & $\begin{array}{l}\text { It is not possible to give detailed } \\
\text { information about the change. The } \\
\text { results depend on the analyst's } \\
\text { ability to interpret images. Time } \\
\text { consuming and difficult to update } \\
\text { results }\end{array}$ & No & No & No & No & $\begin{array}{l}\text { (Mohamed \& } \\
\text { Mobarak, 2016; } \\
\text { Mausel et al, 2004; } \\
\text { Thomas et al., } \\
\text { 2015) }\end{array}$ \\
\hline
\end{tabular}




\section{Conclusion}

Land cover change is intricate and a continuing process, and is also interconnected such that the extension of one type occurs at the cost of other classes. A millions hectares of land cover changes occur from one type to another within a short period of time worldwide. The expansion of urban settlement at the expense of forest and agricultural land is one of the major land cover change registered. The population changes and the expansion of megacities are leading to the transformation of forests and agricultural areas into urban agglomerations. These LCC have both positive and negative consequences. On the positive side, some changes in LULC have paid a substantial profit in terms of human welfare and economic growth. However, these advances were experienced at ahigh loss in the form of distraction of uncountable ecosystem services, amplified jeopardies of nonlinear changes and the escalation of poverty for some groups of peoples. Rapid growth and enlargement of urban centers, rapid population growth, migration to cities, the shortage of land, the need for more production, policy reforms, and high land value, lack of coordination between institutions, corruption, unplanned resettlement programs and change of technologies are among the many drivers of LULCC in today's world. Spatially integrating RS and GIS can produce powerful technique for optimal LULC planning and monitoring. Therefore understanding, analyzing, monitoring and evaluation of dynamics of LCC by using Geo-informatics technology like GIS and remote sensing is crucial for better management and knowledge of their essential features, processes, and its environmental consequences to support sustainable development.

\section{Conflict of Interest}

The authors declare that there is no conflict of interest with any financial, personal, or other relationships with other people or organizations related to the material discussed in the article.

\section{References}

Abebe, M. T., \& Megento, T. L. (2016). The city of addis ababa from 'forest city' to 'urban heat island': Assessment of urban green space dynamics. Journal of Urban and Environmental Engineering, 10(2), 254-262. https://doi.org/10.4090/juee.2016.v10n2.254262.

Afify, H. A. (2011). Evaluation of change detection techniques for monitoring land-cover changes: A case study in new Burg El-Arab area. Alexandria Engineering Journal, 50(2), 187-195. https://doi.org/10.1016/j.aej.2011.06.001. 
Al-doski, J., Mansor, S. B., Zulhaidi, H., \& Shafri, M. (2013). Change Detection Process and Techniques. Civil and Environmental Research, 3(10), 37-46.

Ali Khawaldah, H. (2016). A Prediction of Future Land Use/Land Cover in Amman Area Using GIS-Based Markov Model and Remote Sensing. Journal of Geographic Information System, 8(8), 412-427. https://doi.org/10.4236/jgis.2016.83035.

Almutairi, A., \& Warner, T. A. (2010). Change Detection Accuracy and Image Properties : A Study. Remote Sens, 2, 1508-1529. https://doi.org/10.3390/rs2061508.

Alqurashi, A. F., \& Kumar, L. (2013). Investigating the Use of Remote Sensing and GIS Techniques to Detect Land Use and Land Cover Change: A Review. Advances in Remote Sensing, 02(02), 193-204. https://doi.org/10.4236/ars.2013.22022.

Al-wassai, F. A., \& Kalyankar, N. V. (2013). Major limitations of satellite images. Journal of Global Research in Computer Science, 4(5), 51-59.Available Online at www.jgrcs.info

Andreas B. B., Catherine, B., Lukas, B., Pierre, D., Celine, E., Francois, D., Andrea, L.\& Katerina,T. (2013). Anthropogenic pressure in East Africa-Monitoring 20 years of land cover changes by means of medium resolution satellite data. International Journal of Applied Earth Observation and Geoinformation, 28, 60-69. https://doi.org/10.1016/j.jag.2013.11.006.

Awoke, B. G. (2010). The role of geo information technology for predicting and mapping of forest cover spatio-temporal variability: Dendi district case study, Ethiopia. Journal of Sustainable Development in Africa, 12(6), 9-33.

Ayele, A.F., Hiroshi, Y., Nigussie, H., Ashebir, S. B., Zelalem, H., Mewcha, A. G.,and Getachew, M. (2018). The dynamics of urban expansion and land use / land cover changes using remote sensing and spatial metrics : the case of Mekelle City of northern Ethiopia. International Journal of Remote Sensing,38(14), 4107-4129. https://doi.org/10.1080/01431161.2017.1317936.

Azeb ,W.D., Florian, Z., \& Wolfram, M. (2018). Assessing land use and land cover changes and agricultural farmland expansions in Gambella Region, Ethiopia , using Landsat 5 and Sentinel 2a multispectral data. Heliyon, 4, Article No-e00919. https://doi.org/10.1016/j.heliyon.2018.e00919.

Barani, S., Seelam S., Venkatesh A. \& Reddy N.R (2018). Effectiveness of Geographic Information System and Remote Sensing Technology as a Decision Support Tool in Land Administration the Case of Yeka Sub City, Addis Ababa. International Journal of Innovative Research in Science, Engineering and Technology, 7(3), 1942-1948. https://doi.org/10.15680/IJIRCCE.2018.0603029.

Bagan, H., \& Yamagata, Y. (2014). Land-cover change analysis in 50 global cities by using a combination of Landsat data and analysis of grid cells. Environmental Research Letters, 9(6), 2000-2010. https://doi.org/10.1088/1748-9326/9/6/064015.

Battista, G., \& de Lieto Vollaro, R. (2017). Correlation between air pollution and weather data in urban areas: Assessment of the city of Rome (Italy) as spatially and temporally independent regarding pollutants. Atmospheric Environment, 165, 240-247. https://doi.org/10.1016/j.atmosenv.2017.06.050. 
Bay, A. Q., \& El-hattab, M. M. (2016). Applying post classification change detection technique to monitor an Egyptian coastal zone. The Egyptian Journal of Remote Sensing and Space Sciences, 19(1), 23-36. https://doi.org/10.1016/j.ejrs.2016.02.002.

Bisrat, K. A., Gizaw, M. T., Gerrit, H. S., \& Tsegaye, T. (2018). Influence of urbanizationdriven land use/cover change on climate: The case of Addis Ababa, Ethiopia. Physics and Chemistry of the Earth, 105, 212-223. https://doi.org/10.1016/j.pce.2018.02.009.

Charles, G., Julius, M. N., \& Ramadhan, W. S. (2016). Hydrological responses to land use/cover changes in the Olifants Basin, South Africa. Water (MDPI), 8(12), 1-16. https://doi.org/10.3390/w8120588.

Chen, M., Zhang, H., Liu, W., \& Zhang, W. (2014). The global pattern of urbanization and economic growth: Evidence from the last three decades. PLoS ONE, 9(8). https://doi.org/10.1371/journal.pone.0103799.

Chetan, Glen, M., J.Morgan Grove, Tom P.Evans, C. M. schwei. (2002). A Review and Assessment of Land-Use Change Models: Dynamics of Space, Time, and Human Choice. United States Department of Agriculture Northeastern Research Station. Washington, D.C. Retrieved from https://www.nrs.fs.fed.us/pubs/gtr/gtr_ne297.pdf.

Cui, L., \& Shi, J. (2012). Urbanization and its environmental effects in Shanghai, China. Urban Climate, 2, 1-15. https://doi.org/10.1016/j.uclim.2012.10.008.

Dawson, R. J., Hall, J. W. andBarr. (2009). A blueprint for the integrated assessment of climate change in cities. Tyndall Centre for Climate Change Research, (129), 1-26.

Devi, R. N. (2015). Change detection techniques - a sur v ey. International Journal on Computational Science \& Applications, 5(2), 45-57. https://doi.org/10.5121/ijcsa.2015.5205.

Erle Ellis. (2007). Land-use and land-cover change and Climate change. In The Encyclopedia of Earth (p. 4). Washington, D.C.: Environmental Information Coalition, National Council for Science and the Environment. Retrieved from https://web.archive.org/web/20070503192914/http://www.eoearth.org/article/Land-use_ and_land-cover_change.

Faye, L. C., Sambou, H., Kyereh, B., \& Sambou, B. (2016). Land Use and Land Cover Change in a Community-Managed Forest in South-Eastern Senegal Under a Formal Forest Management Regime, 5(1), 1-10. https://doi.org/10.11648/j.ajep.20160501.11.

Galal, E. O., Babiker, A., \& Fatima, A. M. (2015). Assessing the Impact of Different Land Use Activities on the Vegetation Cover and Sustainable Livelihoods along the Banks of Niles at Khartoum State, Sudan. Journal of Geoscience and Environment Protection, 03(03), 52-61. https://doi.org/10.4236/gep.2015.33005.

Gashu, K., \& Egziabher, T. G. (2018). Spatiotemporal trends of urban land use / land cover and green infrastructure change in two Ethiopian cities: Bahir Dar and Hawassa. Environmental Systems Research, 7(8), 0111-3. https://doi.org/10.1186/s40068-0180111-3. 
Gebrekidan, W., Amare, B., and Habtamu T. (2014). Land use and land cover change in Ameleke Watershed, South Ethiopia. Journal of Natural Sciences Research Www, 4(14), 2225-921.

Ghosh, S., \& Das, A. (2019). Remote Sensing Applications : Society and Environment Urban expansion induced vulnerability assessment of East Kolkata Wetland using Fuzzy MCDM method. Remote Sensing Applications: Society and Environment, 13, 191-203. https://doi.org/10.1016/j.rsase.2018.10.014.

Grafius, D. R., Corstanje, R., Warren, P. H., Evans, K. L., Hancock, S., \& and Harris, J. A. (2016). The impact of land use / land cover scale on modelling urban ecosystem services. Landscape Ecology, 31(7), 1509-1522. https://doi.org/10.1007/s10980-0150337-7.

Gregorio, L. J. M. J. and A. Di. (2002). Parametric land cover and land-use classifications as tools for environmental change detection. Agriculture, Ecosystems and Environment, 91(1-3), 89-100. https://doi.org/10.1016/S0167-8809(01)00243-2.

Grimm, B. N. B., Faeth, S. H., Golubiewski, N. E., Redman, C. L., Bai, X., Briggs, J. M., ... Golubiewski, N. E. (2008). Global Change and the Ecology of Cities. American Association for the Advancement of Science, 319(5864), 756-760. https://doi.org/10.1126/science.1150195.Abstract.

Hailemariam, S. N., Soromessa, T., \& Teketay, D. (2016). Land Use and Land Cover Change in the Bale. MDPI Land, 5(41). https://doi.org/10.3390/land5040041.

Afera, H., Asirat, T., Ermias. S., \& Imran, A. (2018). Dynamics of Land Use and Land Cover Change Using Remote Sensing and GIS : A Case Study of Debre Tabor Town, South Gonder, Ethiopia. Geographic Information System, 10, 165-174. https://doi.org/10.4236/jgis.2018.102008.

Hassan, Z., Shabbir, R., Ahmad, S. S., Malik, A. H., Aziz, Neelam, A., \& Butt, A. (2016). Dynamics of land use and land cover change ( LULCC ) using geospatial techniques : a case study of Islamabad Pakistan. SpringerPlus, 5, 812. https://doi.org/10.1186/s40064016-2414-z.

Henderson, J. V and Davis J.C. (2003). Evidence on the political economy of the urbanization process. Journal of Urban Economics, 53(1), 98-125. https://doi.org/10.1016/S0094-1190(02)00504-1.

Hernández-Guzmán, R., Ruiz-Luna, A., \& González, C. (2019). Assessing and modeling the impact of land use and changes in land cover related to carbon storage in a western basin in Mexico. Remote Sensing Applications: Society and Environment, 13, 318-327. https://doi.org/10.1016/j.rsase.2018.12.005.

Herold, M., Scepan, J., \& Clarke, K. C. (2002). The use of remote sensing and landscape metrics to describe structures and changes in urban land uses. Environment and Planning A, 34(8), 1443-1458. https://doi.org/10.1068/a3496.

Jing, Q., Qiming, Z., \& Quan, H. (2007). Comparison of pixel-based and object-oriented classification methods for extracting built-up areas in arid zone. In ISPRS workshop on updating Geo-spatial databases with imagery \& the 5th ISPRS workshop on DMGISs (Vol. 8, pp. 163-171). 
Jokar, J. (2011). Dynamic land use/cover change simulation:Geosimulation and Multi AgentBased Modelling. University of Vienna, Austria. https://doi.org/10.1007/978-3-64223705-8.

Kebede, A. S. (2018). Assessment of Land Use / Land Cover Change Using GIS and Remote Sensing Techniques: A Case Study of Dendi District, Oromiya Regional State , Ethiopia. Journal of Environment and Earth Science, 8(1), 123-128.

Kindu, M., Schneider, T., Teketay, D., \& Knoke, T. (2015). Drivers of land use/land cover changes in Munessa-Shashemene landscape of the south-central highlands of Ethiopia. Environmental Monitoring and Assessment, 187(452). https://doi.org/10.1007/s10661015-4671-7.

Kumar, K. S., Valasala, N. V. A. S. S., Subrahmanyam, J. V. V, Mallampati, M., Shaik, K., \& Ekkirala, P. (2015). Prediction of Future Land Use Land Cover Changes of Vijayawada City Using Remote Sensing and Gis. International Journal of Innovative Research in Advanced Engineering (IJIRAE), 2(3), 91-97. Retrieved from http://www.ijirae.com/volumes/Vol2/iss3/17.MRCE10083.pdf.

Kumar, M., Singh, R. B., Pravesh, R., Kumar, P., Tripathi, D. K., \& Sahu, N. (2018). Urban growth dynamics and modelling using remote sensing data and multivariate statistical techniques. Current Science, 114(10), 2080-2091. https://doi.org/10.18520/cs/v114/i10/2080-2091.

Lepers, E. (2014). Dynamics of Land -Use and Land-Cover Change in Tropical Regions. Annual Review of Environment and Resources, (June). https://doi.org/10.1146/annurev.energy.28.050302.105459.

Liu, Y. (2009). Exploring the relationship between urbanization and energy consumption in China using ARDL (autoregressive distributed lag) and FDM (factor decomposition model). Energy, 34(11), 1846-1854. https://doi.org/10.1016/j.energy.2009.07.029.

Liu, Z., He, C., Zhou, Y., \& Wu, J. (2014). How much of the world's land has been urbanized, really? A hierarchical framework for avoiding confusion. Landscape Ecology, 29(5), 763-771. https://doi.org/10.1007/s10980-014-0034-y.

Lu, D., \& Moran, E. (2004). Change Detection Techniques. Int. j. remote sensing, 25(12), 2365-2407. https://doi.org/10.1080/0143116031000139863.

Mausel, P., Brondi, E. and Moran, E. (2004). Change detection techniques. International Journal of Remote Sensing, 25(12), 2365-2401. https://doi.org/10.1080/0143116031000139863.

Mcgranahan, G and Ivan, T. (2013). Urbanization and economic growth: The arguments and evidence for Africa and Asia. Environment and Urbanization, 25(2), 465-482. https://doi.org/10.1177/0956247813490908.

Mengistu, T. (2016). Horizontal Urban Expansion And Livelihood Adjustment Problem Among Ex-Farmers In The Kebeles Surrounding Jimma Town: The Case Of Derba Kebele. European Scientific Journal, ESJ, 12(14), 308. https://doi.org/10.19044/esj.2016.v12n14p308. 
Mercy, C. C., Matheaus, K .K., Patrick, D. K, and Patrick, K. (2016). Assessment of Land Use and Land Cover Change Using GIS and Remote Sensing. Remote Sensing \& GIS, 5(4), 2469-4134. https://doi.org/10.4175/2469-4134.1000175.

Mikias, B. M. (2015). Land Use/Land Cover Dynamics in the Central Rift Valley Region of Ethiopia: Case of Arsi Negele District. African Journal of Agricultural Research, 10(5), 434-449. https://doi.org/10.5897/ajar2014.8728.

Mishra, S., \& Dhurvey, P. (2018). Change Detection Techniques in Remote Sensing: A Review Change Detection Techniques in Remote Sensing: A Review. International Journal of Wireless and Mobile Communication for Industrial Systems, 4(1), 1-8. https://doi.org/10.21742/ijwmcis.2017.4.1.01.

Mohamed, N., \& Mobarak, B. (2016). Change Detection Techniques using Optical Remote Sensing : A Survey. American Scientific Research Journal for Engineering, Technology, and Sciences, 17(1), 42-51.

Mohan, M., \& Kandya, A. (2015). Impact of urbanization and land-use/land-cover change on diurnal temperature range: A case study of tropical urban airshed of India using remote sensing data. Science of the Total Environment, 453-465. https://doi.org/10.1016/j.scitotenv.2014.11.006.

Molders, N. (2012). Land-use and land-cover change impact on climate and air quality. (K. H. Lawrence A. Mysak, Ed.). New York: Springer atmospheric annd Oceanographic sciences library 44. https://doi.org/10.1007/978-94-007-1527-1.

Montgomery, M. R. (2008). The urban transformation of the developing world. Science, 319(5864), 761-764. https://doi.org/10.1126/science.1153012.

Mubea, K., \& Menz, G. (2012). Monitoring Land-Use Change in Nakuru (Kenya) Using Multi-Sensor Satellite Data. Advances in Remote Sensing, 01(03), 74-84. https://doi.org/10.4236/ars.2012.13008.

Nation, U. (2018). World Urbanization Prospects: The 2018 Revision. Department of Economic and Social Affairs, Population Division. New York: Department of Economic and Social Affairs. https://doi.org/10.1016/j.ijgo.2007.03.023.

Obodai, J., Amaning, K., Nii, S., \& and Lumor, M. (2019). land cover dynamics using landsat data in a gold mining basin-the Ankobra, Ghana. Remote Sensing Applications: Society and Environment, 13, 247-256. https://doi.org/10.1016/j.rsase.2018.10.007.

Otukei, J. R., \& Blaschke, T. (2010). Land cover change assessment using decision trees, support vector machines and maximum likelihood classification algorithms. International Journal of Applied Earth Observation and Geoinformation, 12, 27-31. https://doi.org/10.1016/j.jag.2009.11.002.

Padmanaban, R., Bhowmik, A. K., Cabral, P., Zamyatin, A., Almegdadi, O., \& Wang, S. (2017). Modelling Urban Sprawl Using Remotely Sensed Data: A Case Study of Chennai City , Tamilnadu. Entropy, 19(163). https://doi.org/10.3390/e19040163. 
Park, N. (2016). Detecting Trends in Landuse and Landcover Change of Nech Sar. Environmental Management, 57(1), 137-147. https://doi.org/10.1007/s00267-015-06030 .

Patra, S., Sahoo, S., Mishra, P., \& Mahapatra, S. C. (2018). Impacts of urbanization on land use /cover changes and its probable implications on local climate and groundwater level. Journal of Urban Management, 7(2), 70-84. https://doi.org/10.1016/j.jum.2018.04.006.

Phinn, S. R. (1998). A framework for selecting appropriate remotely sensed data dimensions for environmental monitoring and management. International Journal of Remote Sensing, 19(17), 3457-3463. https://doi.org/10.1080/014311698214136.

Phiri, D., \& Morgenroth, J. (2017). Developments in Landsat Land Cover Classification Methods : A Review. Remote Sense, 9(967), 1-25. https://doi.org/10.3390/rs9090967.

Pielke, R. A., Pitman, A., Niyogi, D., Mahmood, R., McAlpine, C., Hossain, F., ... de Noblet, N. (2011). Land use/land cover changes and climate: Modeling analysis and observational evidence. Wiley Interdisciplinary Reviews: Climate Change, 2(6), 828850. https://doi.org/10.1002/wcc. 144 .

Popović, Z. (2017). Shifting Between Forests and Adjacent Areas: Ecotones and Zoonoses خ). In Earth Systems and Environmental Sciences (pp. 1-9). https://doi.org/10.1016/b978-0-12-409548-9.10935-2.

Prashant, K. S., Dawei, Han., Miguel, A., Rico-Ramirez., Michaela, B., \& Tanvir, I. (2012). Selection of classification techniques for land use/land cover change investigation. Advances in Space Research, 50(9), 1250-1265. https://doi.org/10.1016/j.asr.2012.06.032.

Reda, A. G. (2017). Framework for Carbon Sequestration and Accounting of SLM Practices for Climate Change Mitigation in Ethiopia. Internationatianal Journal of Environmental Science \& Natural Resources, 4(2), 001-015. https://doi.org/10.19080/IJESNR.2017.04.555631

Roland E. Schulze. (2000). Modelling Hydrological Responses to Land Use and Climate Change: A Southern African Perspective. AMBIO: A Journal of the Human Environment, 29(1), 12-22. https://doi.org/10.1579/0044-7447-29.1.12.

Rozenstein, O., \& and Karnieli, A. (2011). Comparison of methods for land-use classi fi cation incorporating remote sensing and GIS inputs. Applied Geography, 31, 533-544. https://doi.org/10.1016/j.apgeog.2010.11.006.

Russell G. Congalton, K. G. (2009). Assessing the accuracy of remotely sensed data principle and practice (Second). New York: Library of Congress Cataloging-in-Publication Data Congalton,. Retrieved from http://www.crcpress.com.

Sadoun, B., \& Al Rawashdeh, S. (2009). Applications of GIS and Remote Sensing techniques to land use management. In 2009 IEEE/ACS International Conference on Computer Systems and Applications, AICCSA 2009 (pp. 233-237). https://doi.org/10.1109/AICCSA.2009.5069330. 
Sarkar, A. (2018). Accuracy Assessment and Analysis of Land Use Land Cover Change Using Geoinformatics Technique in Raniganj Coalfield Area, India. Environmental Sciences \& Natural Resources, 11(1), IJESNR.MS.ID.555805. https://doi.org/10.19080/IJESNR.2018.10.555805.

Seto, K. C., Guneralp, B., \& Hutyra, L. R. (2012). Global forecasts of urban expansion to 2030 and direct impacts on biodiversity and carbon pools. Proceedings of the National Academy of Sciences, 109(40), 16083-16088. https://doi.org/10.1073/pnas.1211658109.

Seto, K. C., Parnell, S., Masundire, H., Güneralp, B., \& Lwasa, S. (2017). Urbanization in Africa: challenges and opportunities for conservation. Environmental Research Letters, 13(1), 015002. https://doi.org/10.1088/1748-9326/aa94fe.

Shiferaw, A. (2011). Evaluating the land use an land cover dynamics in Borena Woreda of south Wollo highlands, Ethiopia. Journal of Sustainable Development in Africa, 13(1), 87-107.

Song, Y. (2011). Ecological city and urban sustainable development. Procedia Engineering, 21, 142-146. https://doi.org/10.1016/j.proeng.2011.11.1997.

Srivasatava, M.R. and Satyaprakash. (2020). Urban heat island effect over Delhi NCR usingLANDSAT ${ }^{\mathrm{TM}}$ data, Int. J. Global Warming, In press.

Stéphenne, N., \& Lambin, E. F. (2001). A dynamic simulation model of land-use changes in Sudano-sahelian countries of Africa ( SALU ). Agricultural Ecosystems and Environment, 85, 145-161.

Stephen, J., \& Kelley, A. C. (2002). Linking people, pkace, and policy: A GIScience approach. (S. J. and K. A. C.-M. Walsh, Ed.). Austin, USA: Springer science+ buslness media, LLC. https://doi.org/10.1007/978-1-4615-0985-1.

Summers, J. K., Smith, L. M., Case, J. L., \& Linthurst, R. A. (2012). A review of the elements of human well-being with an emphasis on the contribution of ecosystem services. The Royal Swedish Academy of Science, 41(4), 327-340. https://doi.org/10.1007/s13280-012-0256-7.

Tadesse Amsalu, A. M. (2014). GIS Based Soil Loss Estimation Using RUSLE Model: The Case of Jabi Tehinan Woreda, ANRS, Ethiopia. Natural Resources, 05(11), 616-626. https://doi.org/10.4236/nr.2014.511054.

Taha, H. (2008). Urban climates and heat islands: albedo, evapotranspiration, and anthropogenic heat. Energy and Buildings, 96(25), 985-986. https://doi.org/10.1016/S0378-7788(96)00999-1.

Tawhida, A. Y., Abdelrahim, A. M., and Elmugheira, M. I. (2015). Land Use / Land Cover Change Detection due to Urbanization Case Study: Southern part of Khartoum. Journal of Natural Resources and Environmental Study, 6(2), 1-8.

Terefe, T., Feyera, S., \& Moges, K. (2017). The impact of land use/land cover change on ecosystem services in the central highlands of Ethiopia. Ecosystem Services, 23, 47-54. https://doi.org/10.1016/j.ecoser.2016.11.010. 
Tesfa, W. M., Tripathi S.K, \& Deepak, K (2016). Analyses of land use and land cover change dynamics using GIS and remote sensing during 1984 and 2015 in the Beressa Watershed Northern Central Highland of Ethiopia. Modeling Earth Systems and Environment, 2(4), 1-12. https://doi.org/10.1007/s40808-016-0233-4.

Thomas M. Lillesand, Ralph W. Kiefer, J. W. C. (2015). Remote sensing and Image interpretation. Library ofCongress Cataloging-in-Publication (7th ed.). New York.

Tolera, M., Taffa, T., \& Mekuria, A. (2018). Effects of Urban Land Use / Cover Dynamics on Peri-urban. International Journal of Energy and Environmental Science, 3(3), 51-60. https://doi.org/10.11648/j.ijees.20180303.11.

UnitedNation. (2018a). The World 's Cities in 2018. Economics \& Social Affairs. New York.

UnitedNation. (2018b). World Urbanization Prospects:The speed of urbanization around the world. Department of Economic and Social Affairs Population Division, (No. 2018/1), 1-2. Retrieved from https://population.un.org/wup/Publications/Files/WUP2018PopFacts_2018-1.pdf.

Verburg, P. H., van de Steeg, J., Veldkamp, A., \& Willemen, L. (2009). From land cover change to land function dynamics: A major challenge to improve land characterization. Journal of Environmental Management, 90(3), 1327-1335. https://doi.org/10.1016/j.jenvman.2008.08.005.

Walter V. Reid, Harold A. Mooney, Angela Cropper, Doris Capistrano, Stephen R. Carpenter, Kanchan Chopra, Partha Dasgupta, Thomas Dietz, Anantha Kumar Duraiappah, Rashid Hassan, Roger Kasperson, Rik Leemans, Robert M. May, Tony (A.J.) McMichael, Prabhu Pi, and M. B. Z. (2005). Ecosystems and human well- being: Millennium Ecosystem Assessment. (J. S. and A. Whyte, Ed.). Washigton DC: Jose Sarukhan and Anne Whyte. Retrieved from https://www.millenniumassessment.org/documents/document.356.aspx.

Weng, Q and Lu D. (2007). A survey of image classification methods and techniques for improving classification performance. International Journal of Remote Sensing, 28(5), 823-870. https://doi.org/10.1080/01431160600746456.

Weng, Q. (2016). Remote Sensing and GIS Integration. In Encyclopedia of Environmental Management (pp. 2271-2274). https://doi.org/10.1081/e-eem-120001835.

Wossenu, A., \& Assefa, M. M. and. (2016). Landscape Processes in and Hydrological Dynamics, Soils in Varied Climates. (W. A. Assefa M.Melesse, Ed.). switzerland: Springer Geography. https://doi.org/10.1007/978-3-319-18787-7.

Yan, Z. W., Wang, J., Xia, J. J., \& Feng, J. M. (2016). Review of recent studies of the climatic effects of urbanization in China. Advances in Climate Change Research, 7(3), 154-168. https://doi.org/10.1016/j.accre.2016.09.003.

Yared, G., Heyaw, T., Stephan, P., \& Mengistie, K. (2019). Urban green spaces supply in rapidly urbanizing countries: The case of Sebeta Town, Ethiopia. Remote Sensing Applications: Society and Environment, 13(27), 138-149. https://doi.org/10.1016/j.rsase.2018.10.019. 
Yue C., Kang H., Xuxiang Li., \& Yunwei Z, \& Pei Chen (2018). Review of Land Use and Land Cover Change research progress. In IOP Conference Series: Earth and Environmental Science (p. 012087). https://doi.org/10.1088/1755-1315/113/1/012087.

Zhang, M., Huang, X., Chuai, X., Yang, H., Lai, L., \& Tan, J. (2015). Impact of land use type conversion on carbon storage in terrestrial ecosystems of China: A spatial- temporal perspective. Sci. Rep, 5, 1-13. https://doi.org/10.1038/srep10233.

Zhang, P., Rijal, S., Keshtkar, H., Rimal, B., Zhang, L., \& Haack, B. (2018). Land Use/Land Cover Dynamics and Modeling of Urban Land Expansion by the Integration of Cellular Automata and Markov Chain. ISPRS International Journal of Geo-Information, 7(4), 154. https://doi.org/10.3390/ijgi7040154. 